Монастирський Ю.А., Максимова О.С., Потапенко В.В., Максименко І.С. Криворізький національний університет, м. Кривий Ріг, Украӥна

\title{
АНАЛІЗ АДЕКВАТНОСТІ МОДЕЛІ ТЕХНІЧНОЇ ЕКСПЛУАТАЦІї СИСТЕМИ ТЕХНОЛОГІЧНОГО АВТОТРАНСПОРТУ
}

\footnotetext{
Технічна експлуатація кар'єрних самоскидів $є$ важливою складовою експлуатації промислового транспорту. Рівень організації технічного обслуговування й ремонту (ТОР) системи технологічного автотранспорту (СТА) визначає ефективність транспортування гірничої маси і $є$ умовою досягнення тривалого строку служби машин.

Оптимальна організація ТОР можлива за умови проведення системного аналізу, розробки математичної моделі СТА, алгоритму і методики управління процесами планових впливів на кожну машину. Аналіз існуючих моделей виявив ряд недоліків, яких позбавлена створена комплексна математична модель технічної експлуатації системи технологічного автотранспорту, що визначає місце i стан кожного автосамоскида у просторах втрати, підтримання і відновлення працездатності, дозволяє описати процес експлуатації машин із урахуванням усіх технологічних та ресурсних станів техніки, переходів між ними, одночасно досягнувши мінімальних витрат на технічну експлуатацію промислового автотранспорту.

Перед розробкою алгоритму оптимального керування та методики його запровадження, необхідно переконатися в адекватності комплексної математичної моделі та їі придатності до відображення виробничих процесів на практиці.

Виконана параметрична ідентифікація моделі, в ході якої отримана збіжність нормативних та розрахованих статистичними і чисельними методами значень параметрів СТА, котра дозволила зробити висновок, що синтезовано адекватну математичну модель технічної експлуатації системи технологічного автотранспорту, яку цілком можливо застосовувати для оптимізації ії функціонування.

Розраховані оптимальні керуючі впливи у вигляді інтенсивності планових впливів ТОР на кар'єрні самоскиди та інтенсивностей переходів зі станів планових технічних обслуговувань, ремонтів і поточного ремонту машини у стан роботи дозволяють розробити алгоритм і методику динамічного коригування параметрів ТОР кожного автосамоскида, які стануть надійним інструментарієм для створення адаптивної системи технічної експлуатації кар'єрних самоскидів.

Ключові слова: аналіз адекватності, математична модель, технічна експлуатація, кар'єрний самоскид.
}

\section{ВСТУП}

Позиції відкритого способу розробки корисних копалин зміцнюються, питома вага технологічного автотранспорту, який є складовою транспортно-технологічного комплексу кар'єрів, збільшується. Сучасний глибокий кар'єр, представляючи собою величезне енергоємне господарство, містить значний парк транспортних засобів, які здійснюють перевезення добутої гірничої маси. Переробка значних обсягів корисних копалин, що добувається у кар'єрах, спричиняє багато побічних труднощів, пов'язаних, зокрема, з їх транспортуванням. У зв'язку зі значною глибиною кар'єрів України, транспортувати породу стає все складніше. Тому з усією гостротою встає питання створення надійних і ефективних транспортних систем перевезення гірничої маси [1].

\section{АНАЛІЗ ЛІТЕРАТУРНИХ ДАНИХ ТА ПОСТАНОВКА ПРОБЛЕМИ}

Понад дві тисячі автосамоскидів БЕЛАЗ працюють на підприємствах України, що складає більше 90\% загальної кількості кар'єрних самоскидів усіх виробників, присутніх на нашому ринку. Найбільшими об'єктами, які експлуатують техніку БЕЛАЗ є залізорудні гірничо-збагачувальні комбінати (ГЗК) Криворізького залізорудного басейну (Кривбасу), де зосереджено біля третини усього українського парку машин [2], у тому числі понад 200 машин із електромеханічною трансмісією вантажопідйомністю 120-220т, котрі забезпечують основний обсяг транспортування гірничої маси. За останні п'ять років придбано 184 одиниці техніки марки "БЕЛАЗ" (табл. 1), із них 109 кар'єрних самоскидів БЕЛАЗ-75131 вантажопідйомністю 130 т.

Особливістю досліджуваної системи технологічного автотранспорту є те, що вона складається 3 парку кар'єрних самоскидів і функціонує по певних трактах, які задаються конфігурацією доріг для вивозу добутої гірничої маси. Аналітичний огляд основних робіт, спрямованих на вдосконалення 
() Монастирський Ю.А., Максимова О.С., Потапенко В.В., Максименко І.С. 2020

Таблиця 1 Поповнення парку Кривбасу технікою марки "БЕЛАЗ" у 2016-2020 роках

\begin{tabular}{|c|c|c|c|c|c|c|}
\hline Модель, вантажопідйомність, об'єм & 2016p. & 2017p. & 2018p. & 2019p. & 2020p. & 2016-2020 pp. \\
\hline & 1 & & 3 & & & 4 \\
\hline БЕЛАЗ-78221 & & & & & & \\
\hline & & & 2 & 5 & & 7 \\
\hline БЕЛАЗ-78231 & & & & & & \\
\hline & & 1 & 4 & 4 & & 9 \\
\hline & & 2 & 11 & 4 & & 17 \\
\hline & 4 & 7 & 6 & 9 & 1 & 27 \\
\hline & & 1 & 2 & 2 & & 5 \\
\hline БЕЛАЗ-7555В & & & & & & \\
\hline 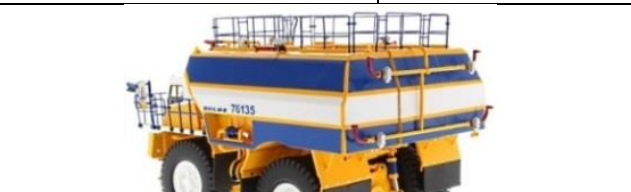 & & & & 3 & & 3 \\
\hline БЕЛАЗ-76135 & & & & & & \\
\hline & & 1 & 2 & & & 3 \\
\hline БЕЛАЗ-7413 & & & & & & \\
\hline & 18 & 32 & 26 & 24 & 9 & 109 \\
\hline БЕЛАЗ-75131 & & & & & & \\
\hline Всього: & 23 & 44 & 56 & 51 & 10 & 184 \\
\hline
\end{tabular}


системи технічної експлуатації технологічного автотранспорту (планування технічного обслуговування й ремонту, зменшення поточних ремонтів (ПоР)) виявив недостатній рівень іiі організації стосовно кар'єрних самоскидів особливо великої вантажопідйомності [3-5].

Незважаючи на наявність значної кількості теоретичних досліджень, відсутні комплексні математичні моделі, які б дозволяли описати експлуатацію машин із урахуванням усіх технологічних та ресурсних станів техніки, переходів між ними, процесів втрати, підтримання та відновлення працездатного стану і одночасно досягти мінімальних витрат на технічну експлуатацію промислового автотранспорту.

Розроблена математична модель експлуатації кар'єрного самоскида БЕЛАЗ для різних рівнів організації технічного обслуговування, діагностування й ремонту, яка відтворює марківський процес, що протікає у системі технологічного автотранспорту й дозволяє обчислювати ймовірності станів машини залежно від часу та у стаціонарних режимах $[6,7]$.

На основі системного підходу досліджене функціонування кар'єрних самоскидів. Моделювання станів і переходів машин дозволило обчислити ймовірності станів системи залежно від часу, дало можливість сформулювати мету і функціонал прибутку від експлуатації системи, описуваної трьома основними станами кар'єрних самоскидів. Варіюючи параметрами функціонала можна досягнути раціональної вартості роботи транспортної системи [8].

На основі розробленої математичної моделі автотранспортної системи залізорудного кар'єру, яка враховує технологічні стани парку автосамоскидів БЕЛАЗ шляхом розрахунків імовірнісних числових характеристик цих станів, синтезоване управління технічною експлуатацією системи на базі економічного критерію, як екстремальної задачі з урахуванням обмежень, пов'язаних із технологічними станами системи [1].

Надійність СТА кар'єру $є$ основним показником як для ефективного управління функціонуванням автосамоскидів, так і для виробництва в цілому. Тривала й надійна робота автосамоскидів можлива за умови своєчасного, систематичного і якісного проведення технічного обслуговування й ремонту, тому обгрунтування параметрів функціонування технологічного автотранспорту глибоких кар'єрів, яке дозволить знизити витрати на технічну експлуатацію автосамоскидів є актуальним науковим завданням.

\section{ЦІЛЬ ТА ЗАДАЧІ ДОСЛІДЖЕННЯ}

Ціллю досліджень є підвищення ефективності експлуатації технологічного автотранспорту глибоких кар'єрів шляхом застосування обгрунтованих параметрів технічного обслуговування й ремонту. Задача вдосконалення системи ТОР відноситься до планування й розробки методів управління технічним обслуговуванням і ремонтом рухомого складу, оптимізації за критерієм мінімізації наведених витрат на послугу "транспортування гірничої маси".

Об'єктом досліджень є процеси технічної експлуатації промислового технологічного автотранспорту глибоких кар'єрів, а предметом - взаємозв'язок параметрів технічного обслуговування й ремонту та техніко-економічних показників технологічного автотранспорту глибоких кар'єрів.

\section{РЕЗУЛЬТАТИ ДОСЛІДЖЕНЬ}

Аналіз системи технологічного автотранспорту глибокого кар'єру дозволив зробити висновок, що на іï ефективність особливий вплив має керуючий параметр, який характеризує та визначає інтенсивність $\lambda$ (рис. 1) проведення планових технічних обслуговувань і ремонтів [7].

Тому представляється доцільним дослідити взаємозв'язок цього параметра 3 іншими параметрами, які характеризують функціонування систем технологічного автотранспорту гірничозбагачувальних комбінатів Криворізького залізорудного басейну.

Із цією метою необхідно підтвердити можливість управління ефективністю СТА шляхом коригування керуючого параметра на основі контролю керованих параметрів. Обгрунтування періодичності технічного обслуговування й ремонту $\epsilon$ одним із основних заходів програми забезпечення надійності кар'єрних самоскидів та політики в області якості ВАТ «БЕЛАЗ».

Ідентифікація системи технологічного автотранспорту виконана на прикладі публічного акціонерного товариства «Центральний гірничо-збагачувальний комбінат» (ПАТ «ЦГЗК»), у якому протягом 2015 року працювали 5 нових гарантійних і 44 негарантійних кар'єрних самоскиди БЕЛАЗ75131 (по 22 машини в гірничотранспортних цехах (ГТЦ) №1 і №2).

Негарантійні кар'єрні автосамоскиди БЕЛАЗ - ті, для яких з початку експлуатації настала одна iз трьох подій: календарний час 12 місяців або напрацювання 6000 мотогод чи пробіг 60000 км. Такі

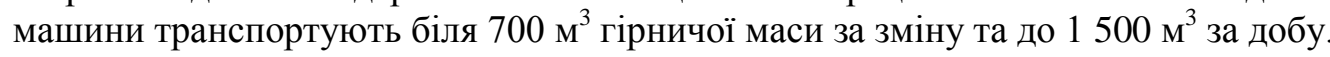


Аналіз функціонування автосамоскидів БЕЛАЗ у кар'єрах ПАТ «ЦГЗК» указує на доцільність проведення параметричної ідентифікації системи технологічного автотранспорту, яка дозволить,

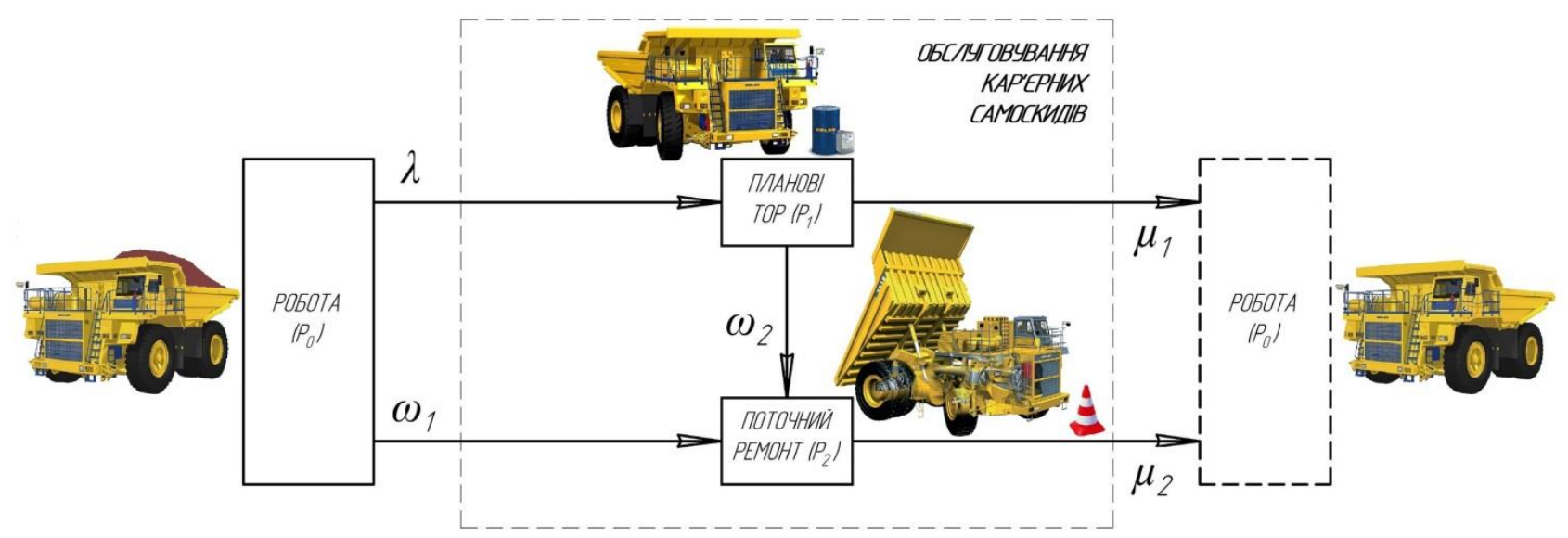

Рисунок 1 - Блок обслуговування кар'єрних автосамоскидів БЕЛАЗ за наявності впливу підблоку ТОР на підблок ПоР

$\lambda$ - інтенсивність переходів кар'єрного автосамоскида зі стану роботи у стан планових ТОР; $\omega_{1}$ - інтенсивність переходів кар'єрного автосамоскида зі стану роботи у стан непланових (ПоР); $\omega_{2} \quad-$ інтенсивність переходів самоскида зі стану ТОР у стан ПоР; $\mu_{1}, \mu_{2}$ - інтенсивності повернень самоскида у стан роботи зі станів планових ТОР і непланових ПоР

спираючись на відповідний статистичний матеріал, визначити величини параметрів математичної моделі СТА як результат структурної ідентифікації.

Критерій оптимальності СТА - мінімум трудомісткості виконаних робіт ТОР

$$
C=c_{1} \cdot N_{1} \cdot T_{1}+c_{2} \cdot N_{2} \cdot T_{2} \rightarrow \min _{\lambda, \omega_{1}, \omega_{2}, \mu_{1}, \mu_{2}},
$$

де $c_{1}$ i $c_{2}$ - середні трудомісткості планових технічних обслуговувань і ремонтів та непланових поточних ремонтів автосамоскидів відповідно, люд·год; $N_{k}$ - число автосамоскидів у $k$-му стані; $T_{k}$ - час перебування самоскидів у $k$-му стані, $(k=1 ; 2)$. Цей критерій дозволяє реалізувати завдання оптимального управління та базується на створеній математичній моделі, яка відтворює марківський процес, що протікає у системі технологічного автотранспорту [8].

Однак попередньо необхідно довести, що можна користуватися реалізацією математичної моделі функціонування СТА у вигляді марківського процесу. Із цією метою розглянемо завдання ідентифікації з функціоналом [9], який мінімізується за тими ж параметрами $\lambda, \mu_{1}, \mu_{2}, \omega_{1}, \omega_{2}$, що i критерій оптимальності СТА (1):

$$
\sum_{i=1}^{N}\left(\left(t_{0 i}-T_{i} \cdot P_{0}\right)^{2}+\left(t_{1 i}-T_{i} \cdot P_{1}\right)^{2}+\left(t_{0 i}-T_{i} \cdot P_{0}\right) \cdot\left(t_{1 i}-T_{i} \cdot P_{1}\right)\right) \rightarrow \min _{\lambda, \omega_{1}, \omega_{2}, \mu_{1}, \mu_{2}},
$$

де $T_{i}$ - час спостереження за технологічними станами $i$-го кар'єрного самоскида, мотогод; $t_{0 i}, t_{1 i}, t_{2 i}$ - сумарний фактичний час знаходження $i$-го кар'єрного самоскида у кожному із трьох технологічних станів протягом часу $T_{i}, \quad$ мотогод; $P_{0}=P_{0}\left(\lambda, \omega_{1}, \omega_{2}, \mu_{1}, \mu_{2}\right)$, $P_{1}=P_{1}\left(\lambda, \omega_{1}, \omega_{2}, \mu_{1}, \mu_{2}\right), \quad P_{2}=P_{2}\left(\lambda, \omega_{1}, \omega_{2}, \mu_{1}, \mu_{2}\right)-$ ймовірності знаходження кар'єрного самоскида у кожному з трьох технологічних станів [7].

Знаходження величин параметрів $\lambda, \mu_{1}, \mu_{2}, \omega_{1}, \omega_{2}$, тобто розв'язання задачі параметричної ідентифікації СТА, проводимо шляхом мінімізації функціонала непогодженостей (2). Для зручності подальших розрахунків записуємо цей функціонал у вигляді 


$$
Q\left(P_{0}, P_{1}\right)=\sum_{i=1}^{N} T_{i}^{2} \cdot\left(\left(\frac{t_{0 i}}{T_{i}}-P_{0}\right)^{2}+\left(\frac{t_{1 i}}{T_{i}}-P_{1}\right)^{2}+\left(\frac{t_{0 i}}{T_{i}}-P_{0}\right) \cdot\left(\frac{t_{1 i}}{T_{i}}-P_{1}\right)\right) \rightarrow \min _{\lambda, \omega_{1}, \omega_{2}, \mu_{1}, \mu_{2}}
$$

i застосовуємо відповідні ймовірності $P_{0}, P_{1}$ як параметри, де $P_{0}=P_{0}\left(\lambda, \omega_{1}, \omega_{2}, \mu_{1}, \mu_{2}\right)$, $P_{1}=P_{1}\left(\lambda, \omega_{1}, \omega_{2}, \mu_{1}, \mu_{2}\right)$.

Шляхом мінімізації функціонала (3) за визначеними параметрами знаходимо оптимальні величини як результат параметричної ідентифікації СТА. Враховуючи досить простий вигляд функціоналу (3), завдання мінімізації вирішуємо аналітично. Згідно до необхідної умови існування екстремуму, прирівнюємо частинні похідні за параметрами $P_{0}$ і $P_{1}$ нулю

$$
\begin{aligned}
& \left\{\begin{array}{l}
\frac{\partial}{\partial P_{0}} Q\left(P_{0}, P_{1}\right)=\sum_{i=1}^{N} T_{i}^{2} \cdot\left(-2 \cdot\left(\frac{t_{0 i}}{T_{i}}-P_{0}\right)-\left(\frac{t_{1 i}}{T_{i}}-P_{1}\right)\right)=0 ; \\
\frac{\partial}{\partial P_{1}} Q\left(P_{0}, P_{1}\right)=\sum_{i=1}^{N} T_{i}^{2} \cdot\left(-2 \cdot\left(\frac{t_{1 i}}{T_{i}}-P_{1}\right)-\left(\frac{t_{0 i}}{T_{i}}-P_{0}\right)\right)=0 .
\end{array}\right. \\
& \left\{\begin{array}{l}
2 \cdot P_{0} \cdot \overline{T^{2}}+P_{1} \cdot \overline{T^{2}}=2 \cdot \overline{T \cdot t_{0}}+\overline{T \cdot t_{1}} \\
P_{0} \cdot \overline{T^{2}}+2 \cdot P_{1} \cdot \overline{T^{2}}=2 \cdot \overline{T \cdot t_{1}}+\overline{T \cdot t_{0}}
\end{array} .\right.
\end{aligned}
$$

У результаті маємо систему двох лінійних алгебраїчних рівнянь

$$
\left\{\begin{array}{l}
2 \cdot P_{0}+P_{1}=\frac{1}{\overline{T^{2}}} \cdot\left(2 \cdot \overline{T \cdot t_{0}}+\overline{T \cdot t_{1}}\right) \\
P_{0}+2 \cdot P_{1}=\frac{1}{\overline{T^{2}}} \cdot\left(\overline{T \cdot t_{0}}+2 \cdot \overline{T \cdot t_{1}}\right)
\end{array}\right.
$$

Розв'язуємо цю систему за формулами Крамера, у відповідності до яких система двох лінійних рівнянь із двома невідомими $P_{0}$ і $P_{1}$, визначником матриці системи, який не дорівнює нулю

$$
\Delta=\left|\begin{array}{ll}
2 & 1 \\
1 & 2
\end{array}\right|=3 \neq 0
$$

та визначниками

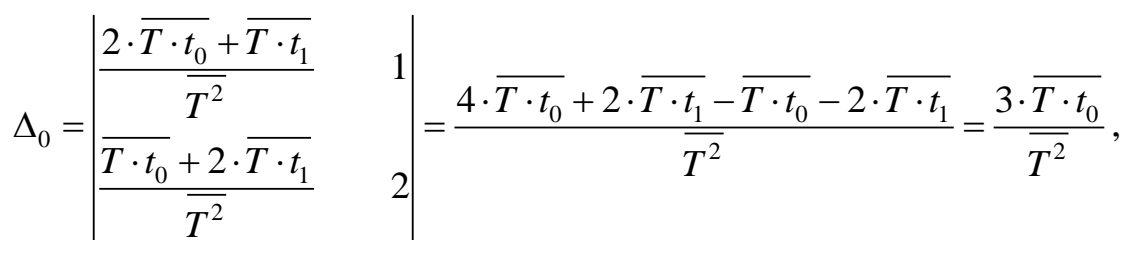

$$
\begin{aligned}
& \Delta_{1}=\left|\begin{array}{ll}
2 & \frac{2 \cdot \overline{T \cdot t_{0}}+\overline{T \cdot t_{1}}}{\overline{T^{2}}} \\
1 & \frac{\overline{T \cdot t_{0}}+2 \cdot \overline{T \cdot t_{1}}}{\overline{T^{2}}}
\end{array}\right|=\frac{2 \cdot \overline{T \cdot t_{0}}+4 \cdot \overline{T \cdot t_{1}}-2 \cdot \overline{T \cdot t_{0}}-\overline{T \cdot t_{1}}}{\overline{T^{2}}}=\frac{3 \cdot \overline{T \cdot t_{1}}}{\overline{T^{2}}}
\end{aligned}
$$

має рішення у вигляді: 


$$
P_{0}=\frac{\Delta_{0}}{\Delta}=\frac{3 \cdot \overline{T \cdot t_{0}}}{3 \cdot \overline{T^{2}}}=\frac{\overline{T \cdot t_{0}}}{\overline{T^{2}}}, P_{1}=\frac{\Delta_{1}}{\Delta}=\frac{3 \cdot \overline{T \cdot t_{1}}}{3 \cdot \overline{T^{2}}}=\frac{\overline{T \cdot t_{1}}}{\overline{T^{2}}}, P_{2}=1-\frac{\overline{T \cdot t_{0}}+\overline{T \cdot t_{1}}}{\overline{T^{2}}} .
$$

У таблиці 2 наведені статистичні дані про роботу підконтрольних автосамоскидів БЕЛАЗ у кар'єрах ПАТ «ЦГЗК» протягом 2015 року (для полегшення проведення параметричної ідентифікації було обрано 4 автосамоскида ГТЦ-1 із господарчими номерами: 324, 325, 326, 327). Апробація досліджень виконується в рамках договорів про співпрацю університету та підприємств компанії "METIHBECT", крім того компанією надані фактичні дані роботи структурних підрозділів за останні роки підчас студентського кейс-чемпіонату в гірничовидобувній галузі, який проводився в 2018-2019 навчальному році. Враховуючи середні значення параметрів, визначених у таблиці 2, за формулами (4) отримуємо значення ймовірностей знаходження автосамоскидів у стані роботи, планових технічних обслуговуваннях і ремонтах та непланових поточних ремонтах відповідно

Таблиця 2 Дані про роботу підконтрольних кар'єрних самоскидів БЕЛАЗ на ПАТ «ЦГЗК» для проведення параметричної ідентифікації

\begin{tabular}{|c|c|c|c|c|c|c|c|c|}
\hline \multirow[t]{2}{*}{ 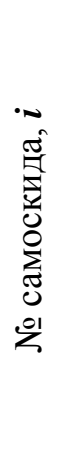 } & \multirow[t]{2}{*}{ 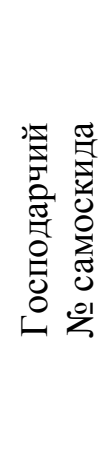 } & \multirow{2}{*}{ 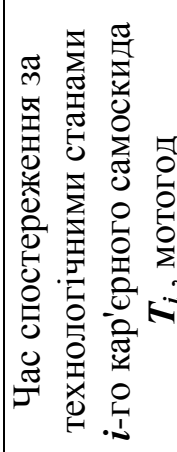 } & \multicolumn{3}{|c|}{$\begin{array}{l}\text { Сумарний час } t_{k i} \\
\text { знаходження } \\
i \text {-го самоскида у } \\
\text { кожному із трьох } \\
\text { технологічних } \\
\text { станів протягом } \\
\text { часу } T_{i}, \text { мотогод }\end{array}$} & \multicolumn{3}{|c|}{ Елементи функціонала, мотогод ${ }^{2}$} \\
\hline & & & $t_{0 i}$ & $t_{1 i}$ & $t_{2 i}$ & $T_{i}^{2}$ & $T_{i} \cdot t_{0 i}$ & $T_{i} \cdot t_{1 i}$ \\
\hline 1 & tit & 8760 & 6950 & 940 & 870 & 76737600 & 60882000 & 8234400 \\
\hline 2 & 41 & 8760 & 7100 & 880 & 780 & 76737600 & 62196000 & 7708800 \\
\hline 3 & tin & 8760 & 7120 & 930 & 710 & 76737600 & 62371200 & 8146800 \\
\hline 4 & ten & 8760 & 7150 & 980 & 630 & 76737600 & 62634000 & 8584800 \\
\hline 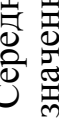 & 4 & 8760 & 7080 & 932,5 & 747,5 & $\overline{T^{2}}=76737600$ & $\overline{T \cdot t_{0}}=62020800$ & $\overline{T \cdot t_{1}}=8168700$ \\
\hline
\end{tabular}

$P_{0}=\frac{\overline{T \cdot t_{0}}}{\overline{T^{2}}}=\frac{62020800}{76737600}=0,808 ; \quad P_{1}=\frac{\overline{T \cdot t_{1}}}{\overline{T^{2}}}=\frac{8168700}{76737600}=0,106 ; \quad P_{2}=1-P_{0}-P_{1}=1-0,808-0,106=0,086$.

Відповідно до «Положення» [10] для кар'єрних самоскидів БЕЛАЗ маємо нормативні ймовірності знаходження машин у стані роботи, планових ТОР та непланових ПоР відповідно

$$
P_{0}=\frac{7200}{8760}=0,822 ; P_{1}=\frac{900}{8760}=0,103 ; P_{2}=\frac{660}{8760}=0,075,
$$

які є достатньо близькими до відповідних значень параметричної ідентифікації (5). 


\section{ОБГОВОРЕННЯ РЕЗУЛЬТАТІВ ДОСЛІДЖЕННЯ}

Значення отриманих величин ймовірностей (5) дозволяє зробити висновок про досить задовільний опис математичною моделлю системи технологічного автотранспорту, тобто вважати модель адекватною. Аналіз функціонала (3) указує на його нелінійну залежність від параметрів, величини яких оптимізуються. Внаслідок цього, було вирішено застосувати чисельні методи для розв'язання завдання мінімізації функціонала (2) - мінімізації непогодженостей. За допомогою обчислювального блока Given-minimize системи автоматизованого проектування Mathcad [11], у першому наближенні знайдені величини параметрів, за яких досягається мінімум функції сумарних непогодженостей:

$$
\lambda^{*}=0,00003015 ; \mu_{1}^{*}=0,0002289 ; \mu_{2}^{*}=0,057 ; \omega_{1}^{*}=0,006 ; \omega_{2}^{*}=0 .
$$

При цьому відповідні ймовірності:

$$
P_{0}=P_{0}\left(\lambda^{*}, \omega_{1}^{*}, \omega_{2}^{*}, \mu_{1}^{*}, \mu_{2}^{*}\right)=0,808, P_{1}=P_{1}\left(\lambda^{*}, \omega_{1}^{*}, \omega_{2}^{*}, \mu_{1}^{*}, \mu_{2}^{*}\right)=0,106
$$

співпали із результатами параметричної ідентифікації (5).

Аналіз функціонування блоку «Обслуговування кар'єрних самоскидів» (рис. 1) указує на те, що під час проведення діагностики ТОР зазвичай не виникає потреби виконання ПоР $\left(\omega_{2} \approx 0\right)$, тобто спостерігається незалежність функціонування підблоків ТОР і ПоР. У такому випадку блок «Обслуговування кар'єрних самоскидів» отримує уточнений вигляд (рис. 2).

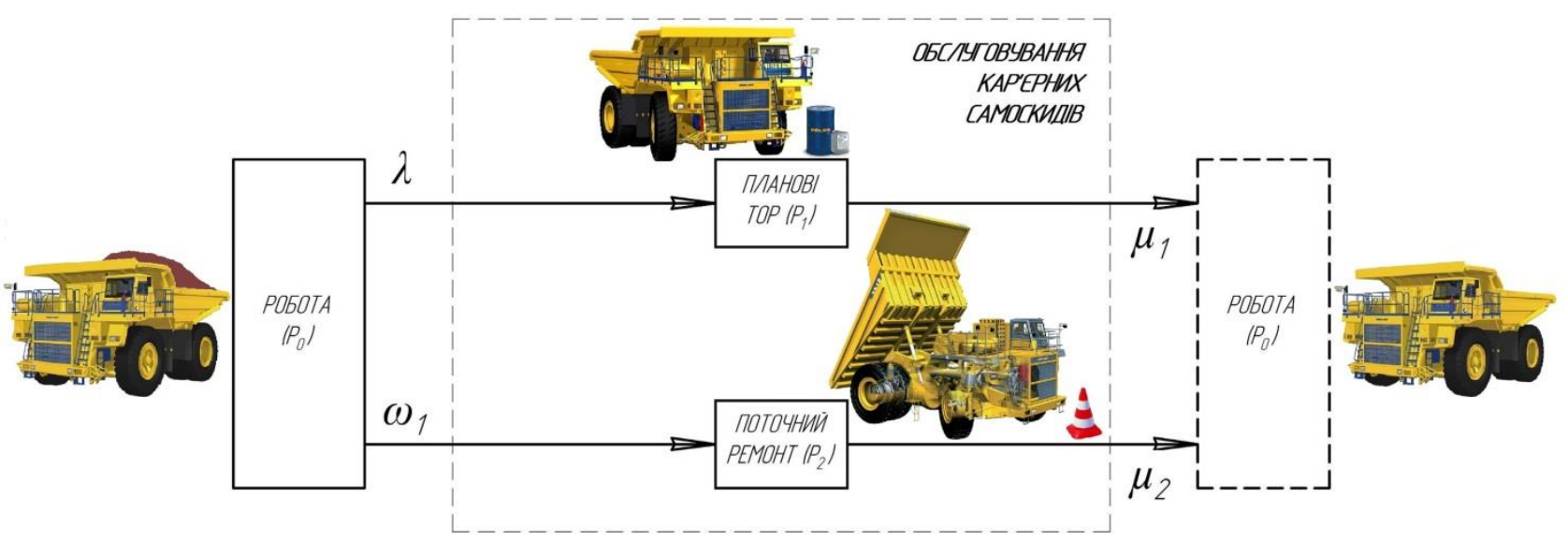

Рисунок 2 - Блок обслуговування кар'єрних автосамоскидів БЕЛАЗ

за відсутності впливу підблоку ТОР на підблок ПоР

Враховуючи відсутність взаємного впливу підблоків ТОР і ПоР $\left(\omega_{2} \approx 0\right)$ та визначені границі припустимих значень нормативних параметрів технічного обслуговування й ремонту технологічного автотранспорту глибоких кар'єрів Криворізького залізорудного басейну, за допомогою обчислювального блока Given-minimize Mathcad знаходимо у другому наближенні величини параметрів, за яких досягається мінімум функції сумарних непогодженостей (4.2):

$$
\lambda^{*}=0,001817 ; \mu_{1}^{*}=0,014 ; \mu_{2}^{*}=0,014 ; \omega_{1}^{*}=0,00143 \text {. }
$$

При цьому ймовірності станів склали величини

$$
P_{0}=P_{0}\left(\lambda^{*}, \omega_{1}^{*}, \mu_{1}^{*}, \mu_{2}^{*}\right)=0,812, P_{1}=P_{1}\left(\lambda^{*}, \omega_{1}^{*}, \mu_{1}^{*}, \mu_{2}^{*}\right)=0,105,
$$

які також є достатньо близькими до відповідних значень параметричної ідентифікації (5).

\section{ВИСНОВКИ}

Ураховуючи отриману збіжність нормативних (6) та розрахованих статистичними (5) та чисельними методами значень параметрів СТА (7) і (8), можна зробити висновок, що синтезовано адекватну математичну модель системи технологічного автотранспорту, яку цілком можливо застосовувати для оптимізації функціонування СТА.

Розраховані оптимальні керуючі впливи у вигляді інтенсивності планових впливів ТОР на кар'єрні самоскиди та інтенсивностей переходів зі станів планових технічних обслуговувань, 
ремонтів і поточного ремонту машини у стан роботи дозволяють розробити алгоритм і методику динамічного коригування параметрів ТОР кожного автосамоскида, які стануть надійним інструментарієм для створення адаптивної системи технічної експлуатації кар'єрних самоскидів.

\section{ПЕРЕЛІК ДЖЕРЕЛ ПОСИЛАННЯ}

1. Монастирський Ю.А. Синтез управління технічною експлуатацією автотранспортної системи залізорудного кар'єру / Ю.А. Монастирський, В.В.Потапенко // Сучасні технології в машинобудуванні та транспорті : наук. журн. / Луц. нац. техн. ун-т. - Луцьк, 2016. - № 1 (5). - С. 110-116.

2. Монастирский Ю.А. Эксплуатация и сервисное обслуживание карьерной техники «БЕЛАЗ» в Украине / Ю.А. Монастирский // Горный журнал. - М., 2013. - №1. - С. 78-80.

3. Карьерный автотранспорт: состояние и перспективы / П.Л. Мариев, А.А. Кулешов, А.Н. Егоров, И.В. Зырянов. - СПб. : Наука, 2004. - 429 с.

4. Карьерный автотранспорт стран СНГ в XXI веке / П.Л.Мариев, А.А.Кулешов, А.Н.Егоров, И.В.Зырянов. - СПб.: Наука, 2006. - 387 с.

5. Карьерные самосвалы особо большой грузоподъёмности. Проектирование, технологии, маркетинг / П.Л.Мариев [ и др. ]. - Минск : Интегралполиграф, 2008. - 320 с.

6. Monastyrskiy, Y. A., \& Potapenko, V. V. (2015). Modeling of technological conditions and analysis of events of functioning BELAZ open pit trucks. Metallurgical and Mining Industry, 7(8), 480-484.

7. Монастирський Ю.А. Математична модель експлуатації кар'єрного самоскида БЕЛАЗ / Ю.А. Монастирський, В.В.Потапенко // Вісник східноукраїнського національного університету імені Володимира Даля. Науковий журнал. - Сєвєродонецьк: СНУ ім. В. Даля, 2015. - № 2 (219). - С. 73-77.

8. Монастирський Ю.А. Системний підхід як метод дослідження функціонування кар'єрних самоскидів / Ю.А. Монастирський, В. М. Серебреников, В.В.Потапенко // Вісник Національного технічного університету «ХПІ». Збірник наукових праць. Серія: Автомобіле- та тракторобудування. -ISSN 2079-0066. Вісник НТУ «ХПІ». 2015. № 9 (1118). - С. 38-44.

9. Монастирський Ю.А. Ідентифікація параметрів моделі автотранспортної системи кар'єру / Ю.А. Монастирський, В.В.Потапенко // Новітні шляхи створення, технічної експлуатації, ремонту і сервісу автомобілів: матер. Всеукраїнської наук.-практ. конф., Одеса - Коблево, 8-11 вересня 2015 року: збірник тез доповідей / - Одеса, Військова академія, 2015. - С. 166-168.

10. Положение о техническом обслуживании, диагностировании и ремонте карьерных самосвалов БелАЗ / РУПП «Белорусский автомобильный завод». А. Н. Егоров [и др.]; под общ. ред. А. Н. Егорова - Жодино : РУПП “БелАЗ”, 2004. - 38 с.

11. Mathsoft Mathcad 11. Users guide, 473 (2002).

\section{REFERENCES}

1. Yu. Monastyrskiy, V. Potapenko. (2016). Synthesis of management of technical operation of motor transportation system of iron ore open pit. Advances in Mechanical Engineering and Transport. 7(8), 110116.

2. Monastyrskiy, Y. A. (2013). Exploitation and after-sales service of open pit equipment "BELAZ" JSC in Ukraine. Gornyi Zhurnal, (1), 78-80. Retrieved from www.scopus.com

3. P.L. Mariev, A.N. Kuleshov, A.N. Egorov, Opencast avtotransp. status and prospects (Science, Spb., 2004).

4. P.L. Mariev, A.N. Kuleshov, A.N. Egorov, Opencast avtotransp. of CIS in 21 century (Science, Spb., 2006).

5. P.L. Mariev, Heavy-duty min. dump trucks. Des., technology, marketing (Interpolygraph, Minsk, 2008).

6. Monastyrskiy, Y. A., \& Potapenko, V. V. (2015). Modeling of technological conditions and analysis of events of functioning BELAZ open pit trucks. Metallurgical and Mining Industry, 7(8), 480-484. Retrieved from www.scopus.com

7. Monastyrskiy Yu., Potapenko V. (2015). Modelling of elements of transport system of dump trucks BELAZ. Visnik of Volodymyr Dahl East Ukrainian National University 2(219), 73-77. ISSN 1998-7927.

8. Monastyrskiy, Y., Serebrenykov, V., Potapenko, V. (2015). System approach as a research method of open pit truck functioning. The bulletin of NTU "KhPI". Series: Car and tractor construction. - Kharkiv: NTU "KhPI", (9), 38-44. ISSN 2079-0066. 
9. Yu. A. Monastyrskiy, Identification of parameters of open pit transportation system model. Paper presented at the Novitni shlyahi stvorennya, tehnichnoyi ekspluatatsiyi, remontu i servisu avtomobiliv (The cutting-edge ways of vehicles design, operation, repair and service), Viyskova akademiya, Odessa, 8-11 September 2015.

10. Polozhenie o tehnicheskom obsluzhivanii, diagnostike, remonte karernyih samosvalov BelAZ (Regulation on the maint., diagnosis and repair of BelAZ min. dump trucks ("BelAZ", Zhodino, 2004).

11. Mathsoft Mathcad 11. Users guide, 473 (2002).

Yu. Monastyrskiy, O. Maksymova, V. Potapenko, I. Maksymenko, Analysis of the appropriate model of the system of technological motor transport. Open-pit truck technical operation is an essential component of the industrial transport operation. The organization level of the system of maintenance and repair of technological automotive transport specify the effectiveness of mined bulk transportation and play a role of vehicles long-term service condition. The optimal organization of maintenance and repair is probable in case of system analysis providing, technological automotive transport system development, algorithm and technique of control of scheduled actions on every vehicle. The analysis of current models showed the number of shortcomings from which designed a complex mathematical model of technological automotive transport maintenance and repair system is free that determine position and state of every open-pit truck in space of loss of function, maintenance and recovery, permit a description of vehicles operation considering technological and resourceful states of equipment, state transitions there between, at the same time finding a way of minimization of industrial transport service costs. Before the design of an optimal control algorithm and technique of its implementation, the verification of complex mathematical model adequacy and its availability in the real world has required. The parametric identification of the model is carried out during which the convergence of specified values of technological automotive transport system parameters with values calculated by statistical and numerical methods was obtained. It arrived at the conclusion that adequacy model of technological automotive transport system technical operation was produced which can be used for its functioning optimization.

The calculated optimal controlling actions in terms of the degree of scheduled actions of maintenance and repair on the open-pit trucks and level of transitions from preventive maintenance states to operation state allow developing an algorithm and technique for dynamic adjustment of parameters of maintenance and repair of every open-pit truck that will become the reliable basis for adaptive open-pit truck operation system design.

The keywords: adequacy analysis, mathematical model, technical operation, open-pit truck.

МОНАСТИРСЬКИЙ Юрій Анатолійович, доктор технічних наук, професор, завідувач кафедри автомобільного транспорту Криворізького національного університету, e-mail: monastirskiy08@ukr.net. https://orcid.org/0000-0002-8282-3929

МАКСИМОВА Олена Сергіївна, кандидат технічних наук, доцент кафедри автомобільного транспорту Криворізького національного університету, e-mail: maxlenser@ukr.net. https://orcid.org/0000-0001-7253-0105

ПОТАПЕНКО Володимир Володимирович, старший викладач кафедри автомобільного транспорту Криворізького національного університету, e-mail: romantihk@gmail.com. https://orcid.org/0000-0003-1439-1017

МАКСИМЕНКО Іван Сергійович, аспірант Криворізького національного університету, e-mail: : ivan2020maksimenko@gmail.com. https://orcid.org/0000-0002-8285-9606

Yuri MONASTYRSKIY, Doctor of Technical Sciences, Professor, Head of Automobile Facilities Department, Kryvyi Rih National University, e-mail: monastirskiy08@ukr.net. https://orcid.org/0000-0002$\underline{8282-3929}$

Olena MAKSYMOVA, $\mathrm{PhD}$ in Engineering, Associate Professor of Automobile Facilities Department, Kryvyi Rih National University, e-mail: maxlenser@ukr.net. https://orcid.org/0000-0001-7253-0105

Volodymyr POTAPENKO, Senior lecturer of Automobile Facilities Department, Kryvyi Rih National University, e-mail: romantihk@gmail.com. https://orcid.org/0000-0003-1439-1017

Ivan MAKSYMENKO, Graduate Student of Kryvyi Rih National University, e-mail: ivan2020maksimenko@gmail.com. https://orcid.org/0000-0002-8285-9606

DOI: 10.36910/automash.v2i15.395 